\title{
The Effectiveness of the Implementation on Parate Execution of Mortgage Right as Alternative in Resolving Problematic Loans at Banking Institutions in Pekanbaru
}

\author{
Nino Sampurno*, Surizki Febrianto and Yusri Munaf \\ Pascasarjana Ilmu Hukum, Universitas Islam Riau, 113, Jalan. Kaharuddin Nasution, Pekanbaru, Riau-28284, \\ Indonesia \\ *Corresponding author email: surizkifebrianto@law.uir.ac.id
}

\begin{abstract}
Absract. The research entitled "TheEffectiveness of the Implementation on Parate Execution of Mortgage Right as an Alternative in Resolving Problematic Loans at Banking Institutions in Pekanbaru" is motivated by the large number of financial institutions that function distribute the loans to the public. Lending begins with a loan agreement between the creditor and debtor and submission of collateral as a guarantee for the fulfilment of loan payments by the debtor. Problematic loans are a risk in lending to the public and problematic loans must be resolved quickly by the bank as the creditor. Article 6 of Law No. 4 of 1996 concerning Mortgage Rights to Land and Objects Related to Land, asserts that if the debtor is in breach of contract, the first Mortgage holder has the right to sell the object of the Mortgage on its own power through a public auction and take the payment of the debt from the proceeds of the sale, which is known as the Execution Parate. The purpose of this research was to discover the effectiveness of the implementation on Parate Execution of Mortgage Right as an alternative in resolving problematic loans and the obstacles of the implementation on Parate Execution of Mortgage Right at Bank Institutions in Pekanbaru. Dealing with the type of research, this research was included in the normative-empirical (applied) legal research class, while by its nature, this research was descriptive analytical.
\end{abstract}

Keywords: Parate Execution, Mortgage Right, Banking Institutions

\section{INTRODUCTION}

The growth of the Indonesian economy as a part of national development is an effort to create a just and prosperous people's welfare based on Pancasilaand the 1945 Constitution[1]. One of the factors that support the implementation of development in the economic sector is the availability of funds. However, people sometimes do not have sufficient budget funds to finance all necessities in carrying out their daily lives. Sources of loan funds are certainly needed in this case so that the needs andactivities of the community concerned can be realized properly.

Banks as financial institutions have strategic value in developing the economy of a country[2]. Lending funds through banks is the most common way to get loan funds where the source of funds owned by the Bank is obtained from the community which is circulated back into the community itself in the form of credit. Therefore, the Bank is often seen as an intermediary institution between the surplus spending group and deficit spending group[3]. Through the distribution of such funds, the objectives of the Bank in implementing national development can be fulfilled where people who need funds can prosper their lives and produce businesses that support national development.

Credit is based on agreement and approval. The interaction between creditors and debtors is then stated in an agreement known as a credit agreement. The credit agreement contains provisions for the amount of credit, the term of the credit, the purpose of using the credit, the interest rate, the method of withdrawing credit funds, the schedule for repayment of credit, and other terms that are no less important, such as provisions regarding collateral for credit[4]. A credit agreement is a legal act. This agreement is evidence that one party promises the other to carry out something. The agreement is the source of the existence of an engagement other than the law. Article 1233 of the Civil Code states: "An engagement is born because of an agreement or because of a law". Article 1338 of the Civil Code states: "all agreements made in accordance with the law shall be valid as law for those who make them". Article 1 paragraph 23 of Law Number 10 of 
1998 concerning Amendments to Law Number 7 of 1992 concerning Banking states[5]: "Collateral is an additional guarantee submitted by debtor customers to the Bank as a form of providing credit or financing facilities based on sharia principles." In the case of collateral for credit facilities provided by banks, land and buildings are general guarantees given by debtors to creditors. In this case, the land title certificate is proof that the debtor is the legal owner of the guarantee given to the Bank. Ownership certificate serves as evidence that gives the right and power to the bank (creditor) to get repayment if the debtor fails to promise by not paying back his debt at the time specified in the agreement. This is done as a solution to anticipating if a problem occurs at a later date and as an effort to provide legal certainty to the parties concerned.

If the collateral given is land and buildings as collateral for credit, it must first be tied up with an institution called Mortgage Rights. Law No. 4/1996 regulates Mortgage Rights on land and objects related to land. In this Law, Article 1 states the following definition of Mortgage Rights: "Mortgage rights over land and objects related to land, hereinafter referred to as Mortgage Rights, are collateral rights imposed on land rights as referred to in Law Number 5 of 1960 concerning Basic Agrarian Principles, together or not together with other objects which are an integral part of the land, for the settlement of certain debts, which give priority to certain creditors over other creditors." [6]

With the existence of a guarantee bond by the Mortgage Institution, the creditor in this case will have executive power if the debtor fails to promise. Not all credit facilities to the public can run smoothly with the instalments. This is because there are certain conditions where the debtor on his credit journey experiences difficulties in fulfilling payment obligations, which may be due to economic conditions. As a result of the problems that exist on this kind of debtor, it will affect the bank as the credit provider. This is one of the risks in providing credit to the community.

The risk of payment failure or what is often referred to as non-performing loans must be addressed as early as possible by the Bank. If not, this could affect the stability of the bank. If the Bank is unable to solve the problem quickly, the percentage of NPL (Non-Performing Loans) to total credit loans will increase. If the increase in NPL continues to a certain number, the bank cannot provide credit to the public.
Every bank certainly has alternatives to salvage the non-performing loans, including:[7]

- Rescheduling, namely changes in credit terms, concerning the payment schedule and / or period including the grace period and changes in the amount of instalments;

- Reconditioning, that is a change in part or all of the credit terms which is not limited to changes in the payment schedule, term, interest rate, postponement of payment of part or all of the interest and other terms;

- Restructuring, it is a change in credit terms in the form of additional bank funds and / or conversion of all or part of arrears of interest into new loan principal.

This policy cannot be given by the bank to all debtors. It is only applicable to those who have good and honest intentions and character and still have the ability to pay or repay credit. However, if the debtor no longer has the ability to repay the debt and added that he does not show good intention and character to the bank, the bank will take legal action in the form of execution of the collateral submitted by the debtor to the creditor as collateral. This execution is the last effort taken by the bank given this process takes a long time and consumes a large amount of funds in its implementation.

The existence of the Mortgage Institution as a result of the issuance of Law Number 4 of 1996 concerning Mortgage Rights to Land and LandRelated Objects on April 4, 1996, has been very welcomed by banking actors in Indonesia. This Mortgage Institution is highly appreciated because it provides convenience and legal certainty for creditors who hold collateral who previously had to use a mortgage institution to execute the guarantee. This law makes it easy for creditors to execute collateral in the form of land and buildings if the debtor is negligent or has failed to fulfil his obligations.

In Law Number 4 of 1996 concerning Mortgage Rights on Land and Objects Related to Land, it is stated in the provisions of Article 6 as follows: "If the debtor defaults, the holder of the first Mortgage has the right to sell the object of the Mortgage on his own power through a public auction and collect the debt from the sale proceeds. "In the Civil Code, this is known as the Parate Execution which is stated in article 1178 paragraph (2) which is as follows:[8] "Any agreement that stipulates that the creditor is given the power to make the pledged goods his property is void. However, the first mortgage creditor, at the time of submission of the mortgage, 
may strictly require that if the principal debt is not paid properly, or if the interest owed is not paid, he will be absolutely authorized to sell the bound parcel in public, so that from the proceeds are paid in full, both the amount of the principal debt as well as the interest and costs. The agreement must be registered in public registers, and the auction must be carried out in the manner ordered in article 1211".

Creditors who hold Mortgage Rights through the Parate Execution no longer need to get approval from the debtor who gives Mortgage Rights. Creditors in this case also do not need to ask for an order from the Chairman of the local Court when they should carry out the execution of the Mortgage Right which is a debt guarantee by the debtor in the event that the debtor cannot fulfil his obligations. Creditors can directly come and submit a request to the local Head of the State Wealth and Auction Service Office (KPKNL) to carry out an auction of the object of the related Mortgage Rights. This method is a new policy that is carried out in terms of execution of Mortgage objects after the Law of Mortgage is promulgated. Prior to the issuance of the Mortgage Rights Law, execution of mortgage gross certificates could only be carried out through the execution of the local District Court[9].

The auction arrangement has been arranged since 1908 with the enactment of the VerduReglementStbl. 1908 Number 189 and Verdu Instruct Stbl. 1908 Number 190 as amended by Stbl. 1940 Number 56, which in article 1 it is stated: "For the application of this rule from the implementing regulations that have been and will be stipulated based on this regulation, what is meant by 'general sales' (Ovenbarevercopingen) is the auction or sale of goods made to the public at an increasing or decreasing bid price or by the inclusion of the price in a closed envelope, or to persons invited or previously notified of the auction or sale or permitted to participate and given the opportunity to bid on a price, agree on a price offered or put a price on a closed envelope. "[10]

Now the auction for the execution of the Mortgage is carried out by the State Wealth and Auction Service Office (KPKNL) based on Regulation of the Minister of Finance Number 27 /
PMK.06 / 2016 concerning Guidelines for Auction Implementation, which it is stated in article 1 paragraph 4 as follows [11]: "The Execution Auction is an auction to carry out a court decision or order, other documents equivalent to it, and or to implement the provisions of the Legislation."

The dominance of the execution of mortgage rights can be seen from the development of auctions which have increased from year to year. Based on the evaluation data on the development of the national auction in 2015, it is known that the frequency of execution auctions for mortgage rights reached 40,977 and reached 44,139 in 2016. However, the high demand for auction for execution of mortgage rights is not necessarily followed by significant auction results. Of the total applications of 44,139 in 2016 , only 4,899 were sold or $11 \%$. This indicates that $89 \%$ of mortgage auctions are unsuccessful or cancelled. The facts show that many auction applications were submitted at the end of the year. Creditors in this case are then allegedly not serious and are only pursuing the target regardless of whether the asset is sold or not [12].

An auction of mortgage rights conducted directly by creditors carries a high risk of lawsuits or resistance, both from debtors and from third parties. This can be seen from the number of active cases handled by DJKN in 2016, which amounted to 2,681 cases which constituted a lawsuit for the execution of mortgage rights out of a total of 3,369 cases." [13]

\section{RESEARCH METHODS}

This research is a research of the Law of Observation (observational research) using descriptive analytical. The object of this research is related to the implementation of the Parate Execution Mortgage Rights as an alternative to solving non-performing loans at PT. Panin Bank Pekanbaru. This research was conducted at the PT. Panin Bank Pekanbaru, State Property and Auction Service Office (KPKNL) Pekanbaru City and Pekanbaru District Court. The population in this study were 1 person of the head of PT. Panin Bank Pekanbaru, 1 person of the Head of the Pekanbaru City Wealth and Auction Service Office (KPKNL) and 1 person of the Head of Pekanbaru District Court.

TABLE 1. the List of Population and Respondents

\begin{tabular}{|l|l|l|l|l|}
\hline No. & Population & Respondent & Percentage & Information \\
\hline 1 & $\begin{array}{l}\text { Head of PT. Panin Bank } \\
\text { Pekanbaru }\end{array}$ & 1 person & $100 \%$ & Census \\
\hline
\end{tabular}




\begin{tabular}{|l|l|l|l|l|}
\hline 2 & $\begin{array}{l}\text { Head of the Pekanbaru } \\
\text { KPKNL }\end{array}$ & 1 person & $100 \%$ & Census \\
\hline 3 & $\begin{array}{l}\text { Chairman of the } \\
\text { Pekanbaru District Court }\end{array}$ & 1 person & $100 \%$ & Census \\
\hline
\end{tabular}

Source: Field Data, July 2019.

The technique used to collect data in this study is interviews. This technique is done by conducting direct questions and answers with the Head of PT. Panin Bank Pekanbaru, Head of the State Wealth and Auction Service Office (KPKNL) and Chairman of the Pekanbaru District Court. The collected data are then grouped according to their respective types. Quantitative data is presented in tabulated form, while qualitative data is presented in clear and detailed sentences. Further analysis is carried out on these data by linking theories, opinions of relevant experts and applicable laws and regulations. After analysis, the next step is drawing conclusions. The inductive method is used in the conclusion stage. This is drawing conclusions from things that are specific to things that are general.

\section{RESULT AND DISCCUSION}

\subsection{The Implementation of Mortgage Parate Execution as an alternative to solving non performing loans at the banking institution in Pekanbaru.}

Non-performing loans are a risk that cannot be avoided in the activity of providing credit facilities by Banks to their debtors. The term of nonperforming loan classification is a term commonly used to describe the quality of credit itself [14]. The provision of credit by Panin Bank Pekanbaru as a creditor to debtors certainly requires supervision. It aims so that the credit provided can run smoothly and can be returned according to the agreed time. The classification of debtors and how to overcome them is carried out by the Panin Bank Pekanbaru as follow:

\subsection{Constraints found by banking institutions in Pekanbaru in the implementation of the Mortgage Parate Execution}

Article 6 of the Mortgage Rights Law which regulates the Parate Execution is actually a way out for the creditor if the debtor is in default or in default of the credit agreement in fulfilling his loan repayment obligations. However, in its implementation practice, there are still a number of obstacles experienced by Panin Bank Pekanbaru in this regard, both those faced at the beginning of the execution parete and after the execution of the Execution Parete.

\section{CONCLUSION}

The conclusions obtained based on the research results and discussion of the issues raised is as follows:

- Banking institutions, in this case Panin Bank Pekanbaru, classify credit quality into categories: Current, Special Mention, Substandard, Doubtful and Loss.Iin every credit quality Panin Bank has settlement and collection efforts starting from billing by telephone, making visits to the debtor's home, office or place of business, giving warning letters 1,2 , and 3 and the last one is trying to salvage the credit by extending the credit period, lowering bank interest rates to reducing interest rates and penalties if the debtor is able to make repayments. Parate Execution conducted by Panin Bank Pekanbaru also plays a very important role in resolving non-performing loans at the Bank. Parate of Mortgage Execution in this case acts as an effective and efficient alternative to solving problem loans. The Parate Execution has succeeded quantitatively in reducing the number of non-performing loans at Panin Bank Pekanbaru. Panin Bank Pekanbaru stated that Parate Execution is the last alternative that can be done in dealing with nonperforming loans settlement. From the data obtained, it was found that the mortgage rights parate execution was not carried out in 2018 due to the relatively small percentage of nonperforming loans at Panin Bank Pekanbaru in that year so that the settlement of nonperforming loans can still be done by making periodic billing and other credit salvage.

- In the parate execution of mortgage rights at Panin Bank Pekanbaru, the obstacles experienced were finding a buyer at the mortgage execution auction. This obstacle occurs due to the poor condition of the collateral when it is sold, the public's ignorance of purchases through auction, as well as concerns about future ownership problems and control of the auction object by the debtor. Not only that, there are other obstacles faced by Panin Bank 
Pekanbaru, namely resistance to the auction of the execution of the mortgage rights from debtors and third parties. However, this problem did not occur much because it had been anticipated by the choice of method of execution, either through parate execution or execution title through court order.

\section{REFERENCES}

[1] Elucidation of Law, concerning Mortgage Rights to Land along with objects related to land. 1996.

[2] Trisadini P. Usanti, Abd. Shomad, HUKUM PERBANKAN, Kencana, Jakarta, First Edition, 2016, p.1. 2016.

[3] Adrian Sutedi, mplikasi Hak Tanggungan Terhadap Pemberian Kredit oleh Bank dan Penyelesaian Kredit Bermasalah, BP Citpta Jaya, Jakarta, 2006, p. 11. 2006.

[4] M. Bahsan, Hukum Jaminan dan Jaminan Kredit Perbankan Indonesia, PT. Raja Grafindo Persada, Jakarta,2007, p. 73. 2007.

[5] Article 1 Number 1 paragraph 23, of Law Number 10 Year 1998 Concerning Amendments to Law Number 7 Year 1992 Concerning Banking.. 1992.

[6] Law Number 4 of 1996, concerning Mortgage Rights to Land and Objects related to land, Article 1 paragraph 1. 1996.

[7] Indonesian Bankers Association, BISNIS KREDIT PERBANKAN, PT. Gramedia Pustaka Utama, Jakarta, 2015, p. 96-98”. 2015.

[8] Collector: Solahuddin, Kitab Undangundang Hukum Perdata, Visimedia, Jakarta, Firt Edition, 2007, p 307. 2007.

[9] Remy Sjahdeini, Hak Tanggungan, Asasasas, Ketentuan-ketentuan Pokok dan masalah yang dihadapi oleh perbankan, Alumni, Bandung, 1999, p. 46. 1999.

[10] https://jdih.kemenkeu.go.id, fullText/1908/189-1908-VR.htm (diakses, Rabu 22 Mei 2019). . 